\title{
Detection of hepatitis B virus DNA in serum using synthetic non-radioactive oligonucleotides
}

\author{
A MANZIN, P PAURI, P BAGNARELLI, F BRECCIAROLI, P E VARALDO, \\ S COLLOCA, * M CLEMENTI $\dagger$ Institute of Microbiology, University of Ancona, Ancona, the \\ *Laboratory of Cell Biology, Istituto Superiore di Sanità, Rome, and the †Institute of Microbiology, University \\ of Trieste, Trieste, Italy
}

SUMMARY A rapid and simplified technique for detecting hepatitis B virus (HBV) DNA by spot hybridisation in the sera of patients with different clinical forms of $\mathrm{HBV}$ infection was investigated using enzyme conjugated synthetic oligodeoxyribonucleotides as probes. These are able to hybridise to the $\mathrm{S}$ and $\mathrm{C}$ regions of the HBV L(-) DNA strand. When compared with a complete ${ }^{32} \mathrm{P}-$ labelled HBV DNA probe, the synthetic oligonucleotides provided a sensitive and quick method for the routine survey of HBV infection. Moreover, the DNA extraction procedure used allowed the spot hybridisation technique to be applied and read easily and the results obtained within a few hours.

It is concluded that synthetic cold probes can be used in hybridisation assays for HBV DNA detection as part of current clinical laboratory procedures.

Hepatitis B virus (HBV) infection is currently a problem of worldwide relevance. ${ }^{\prime}$ Its control at present largely depends on both laboratory diagnosis and evaluation of infectivity, ${ }^{2}$ and molecular hybridisation techniques have provided a sensitive and specific approach to the detection of HBV DNA sequences in serum samples and tissues. ${ }^{3}$ Moreover, when a large number of samples needs to be tested for routine purposes, these methods represent a quick and useful tool for the widespread survey of the infection. ${ }^{46}$ The availability of radiolabelled DNA probes for routine diagnosis, however, is limited to a few laboratories because of the need for propagating, isolating, purifying and labelling procedures. Moreover, as autoradiography requires from $\mathbf{4 8}$ hours to two weeks for the results to be read, the use of such probes does not allow a rapid diagnosis to be made. On the other hand, production of biotinylated ${ }^{7}$ HBV DNA probes has only partially overcome this problem. In fact, hybridisation by cloned, complete biotinylated probes, detected by complexing with streptavidin conjugated to an enzyme, has been shown to be relatively insensitive in some circumstances, ${ }^{8}$ compared with the ${ }^{32} \mathrm{P}$-labelled probes or different cold probes.

As the importance of and the interest in using sensitive non-radioactive HBV DNA probes for routine purposes has been underlined recently ${ }^{9}$ and the

Accepted for publication 25 May 1989 complete sequence of several cloned HBV serotypes is known, ${ }^{1011}$ a potential approach lies in the use of synthetic, enzyme conjugated oligodeoxyribonucleotides as probes which can hybridise to specific sites on the HBV L(-) strand.

To investigate this possibility, synthetic oligodeoxyribonucleotides, which are specifically recognised by fragments of the $S$ and $C$ open reading frames of the HBV genome, were used to test serum samples from different groups of patients infected with HBV.

\section{Material and methods}

Serum samples from $213 \mathrm{HBsAg}$ chronic carriers and 25 patients with acute hepatitis B were tested for the presence of HBV DNA sequences. Serological markers of $\mathrm{HBV}$ infection (HBsAg, anti-HBs, $\mathrm{HBeAg}$, anti-HBe, total anti-HBc and IgM anti-HBc) were detected using a commercially available enzyme immunoassay (EIA) (Connaught Laboratories, Ontario, Canada). Laboratory diagnosis of acute hepatitis B was performed using the methods mentioned above, excluding hepatitis A virus, cytomegalovirus, and Epstein-Barr virus infections, which were assayed using routine EIA methods for specific IgM antibodies.

SYNTHETIC OLIGONUCLEOTIDE PROBES

Sequence data for $a y w,{ }^{10} a d w$, and $a d r$ subtypes ${ }^{11}$ were studied comparatively, and oligonucleotide sequences 
in the $\mathrm{S}$ and $\mathrm{C}$ regions of $\mathrm{HBV}$ DNA were chosen to avoid mismatches greater than $20 \%$. The oligonucleotide sequences for the $\mathrm{S}$ and $\mathrm{C}$ regions of the HBV genome were synthesised and purified using reverse phase high pressure liquid chromatography by Molecular Biosystems (San Diego, California, USA), consisting, respectively, of synthetic 26 and 25 bases complementary to nucleotides from 209 to 234 , and from nucleotides 1983 to 2007 of the ayw L(-) strand. ${ }^{10}$ The probes were covalently linked to alkaline phosphatase at the C-5 position of a thymidine through a 12-atom spacer arm and lyophilised. Finally, the lyophilised probes were resuspended in deionised, sterilised water which resulted in a $10 \mu \mathrm{g} / 100 \mu \mathrm{l}$ stock of each probe.

${ }^{32} \mathrm{P}$-LABELLED PROBE

The probe used was the purified HBV DNA (subtype $a y w$ ) inserted in tandem into the EcoRI restriction site of a pBR322 plasmid ${ }^{10}$ and labelled with ${ }^{32} \mathrm{P}$ d-TTP by the nick translation method ${ }^{12}$; the specific activity was $4-6 \times 10^{8} \mathrm{dpm} / \mu \mathrm{g}$.

\section{NUCLEIC ACID EXTRACTION PROCEDURE}

Serum $(500 \mu \mathrm{l})$ in a final volume of $1.5 \mathrm{ml}$ was incubated at $50^{\circ} \mathrm{C}$ for one hour in $150 \mathrm{mM} \mathrm{NaCl}$, $10 \mathrm{mM}$ EDTA (pH 8.0), $10 \mathrm{mM}$ TRIS- $\mathrm{HCl}$ (pH 8.0), $2 \%$ sodium dodecyl sulphate (SDS), $2.0 \mu \mathrm{g} / \mathrm{ml}$ salmon sperm DNA and $250 \mu \mathrm{g} / \mathrm{ml}$ proteinase K. Afterwards phenol: chloroform: isoamyl alcohol (25:24:1) extraction was performed. Extracted DNA was then precipitated with cold absolute ethanol, dried, and redissolved in $200 \mu \mathrm{l}$ of $10 \mathrm{mM}$ TRIS- $\mathrm{HCl}(\mathrm{pH} \mathrm{7.5)}$ 1 mM EDTA.

\section{DNA:DNA HYBRIDISATION}

For the hybridisation assay using the cold, synthetic probes, redissolved DNA $(50 \mu \mathrm{l})$ was applied to nylon filters (Bio-Rad, Richmond, California, USA) using vacuum filtration apparatus (Bio-Dot Apparatus, Bio-Rad, Richmond, California, USA), and then denatured in situ in $0.5 \mathrm{M} \mathrm{NaOH}, 1.5 \mathrm{M} \mathrm{NaCl}$ for 10 minutes, neutralised in $1.5 \mathrm{M} \mathrm{NaCl}, 0.5 \mathrm{Tris}-\mathrm{HCl}(\mathrm{pH}$ 8.0) for 10 minutes, and then dried for one hour in a vacuum oven at $80^{\circ} \mathrm{C}$.

The filters were pre-hybridised for 15 minutes in pre-warmed hybridisation buffer at $50^{\circ} \mathrm{C}$. The hybridisation solution was $5 \mathrm{x}$ SSC (1x SSC is $0.15 \mathrm{M} \mathrm{NaCl}, 0.015 \mathrm{M}$ sodium citrate), $0.5 \%$ bovine serum albumin (BSA), $0.5 \%$ polyvinylpirrolidone (PVP) and $1 \%$ SDS. The hybridisation was performed at $50^{\circ} \mathrm{C}$ for 30 minutes in the same buffer containing $5 \mu \mathrm{l} / \mathrm{ml}$ of the stock of probes. The filters were washed twice with $50 \mathrm{ml}$ of $1 \times$ SSC, $1 \%$ SDS at room temperature, followed by two washes with $1 \times$ SSC, $1 \%$ Triton X-100 at the hybridisation temperature, and finally two washes with $1 \times$ SSC at room temperature.

Hybridisation with the purified, ${ }^{32} \mathrm{P}$-labelled complete probe was carried out according to Weller et $a l^{13}$ with minor modifications. The filters were hybridised at $42^{\circ} \mathrm{C}$ for $50-60$ hours in $50 \mathrm{ml}$ of a solution containing $50 \%$ formamide, $5 \mathrm{x}$ SSC, $1 \mathrm{x}$ Denhardt's solution (Ficoll 400, PVP 360, BSA $0 \cdot 2$ $\mathrm{mg} / \mathrm{ml}$ each), $0.02 \mathrm{M} \mathrm{NaPi}$ (pH 7.0), 0.05\% SDS, 50 $\mu \mathrm{g} / \mathrm{ml}$ denatured salmon sperm DNA, and $10^{8} \mathrm{dpm}$ of ${ }^{32} \mathrm{P}$-labelled nick-translated HBV DNA probe.

The unincorporated radioactivity was removed by washing out with the following solutions: (i) $5 x$ SSC, $0.1 \%$ SDS, $50 \%$ formamide at $42^{\circ} \mathrm{C}$ for 30 minutes; (ii) $2 \times \mathrm{SSC}, 0.1 \% \mathrm{SDS}$ at $65^{\circ} \mathrm{C}$ for 30 minutes.

\section{HYBRIDISATION DETECTION}

Alkaline phosphatase was detected in $7.5 \mathrm{ml}$ of a substrate buffer (100 mM TRIS-HCl pH 8.5, $100 \mathrm{mM}$ $\mathrm{NaCl}, 100 \mathrm{mM} \mathrm{ZnCP}, 0.02 \%$ sodium azide) containing $33 \mu \mathrm{l}$ of nitro-blue tetrazolium (NBT) and $25 \mu \mathrm{l}$ of 5-bromo-4-chloro-3-indolyl phosphate (BCIP) in $70 \%$ of dimethylformamide. The colour (blue) development was checked after four and 24 hours. Autoradiography was carried out for $\mathbf{4 8}$ hours and for one week at $-70^{\circ} \mathrm{C}$ in a cassette containing Kodak $\mathrm{X}$-Omat $\mathrm{G}$ film and Dupont intensifying screens.

\section{Results}

PRESENCE OF HBV DNA IN SERA OF HBag CHRONIC CARRIERS

Out of $213 \mathrm{HBsAg}$ chronic carriers studied, 39 were $\mathrm{HBeAg}$ positive, 165 anti-HBe positive, and nine were negative for both $\mathrm{HBeAg}$ and anti-HBe. Thirty three of $39(84 \%) \mathrm{HBeAg}$ positive chronic carriers were positive for serum HBV DNA; 21 out of $165(13 \%)$ chronic carriers positive for anti-HBe antibodies had detectable concentrations of HBV DNA in their sera (table 1). Serum HBV DNA was not found in $\mathrm{HBeAg} /$ anti-HBe negative carriers, nor in different groups of subjects negative for serological HBV markers, nor in subjects with anti-HBc or anti-HBs antibodies, or a combination. HBV DNA negative samples were not strongly positive when tested using the ${ }^{32} \mathrm{P}$-labelled HBV DNA, but two $\mathrm{HBeAg}$ and one anti-HBe positive/HBsAg carrier, negative using oligonucleotides, were borderline positive for HBV DNA after one week's exposure to the radioactive probe (table 1).

Furthermore, a sensitivity test was performed using a plasmid control DNA (100 ng/ml) containing $10^{8}$ genomic copies/ng, thus finding a 10-fold and a 20 fold loss of sensitivity when comparing, respectively, the $\mathrm{S}$ and $\mathrm{C}$ probes with the complete, ${ }^{32} \mathrm{P}$-labelled probe (data not shown). 
Table 1 HBV DNA detection by synthetic oligodeoxyribonucleotides in sera of $\mathrm{HBs}$ Ag chronic carriers and patients with acute hepatitis $B$

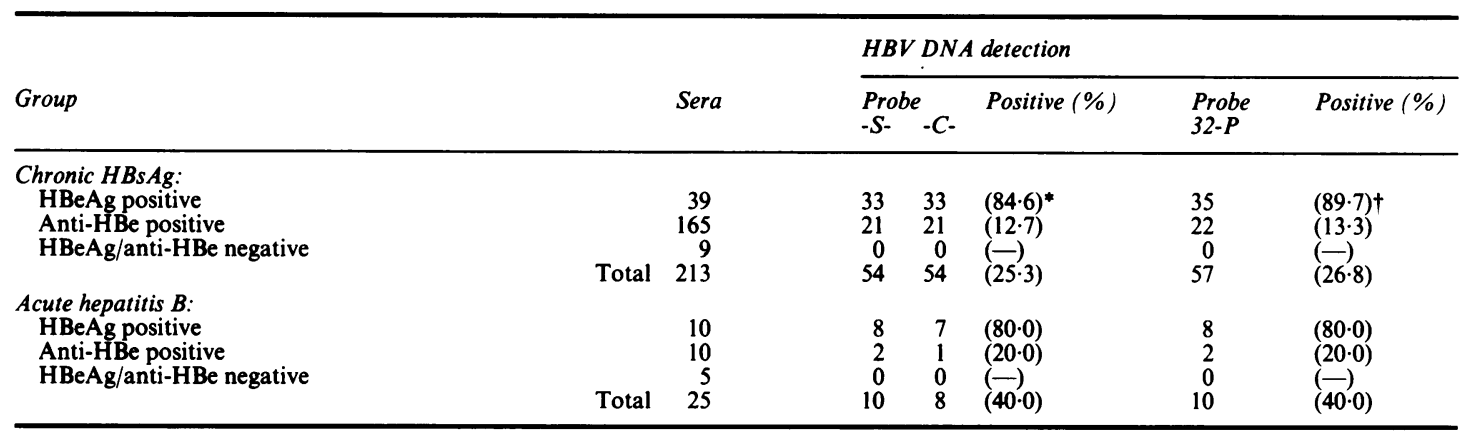

-S- = synthetic oligodeoxyribonucleotides recognised by part of the $\mathrm{S}$ region of the HBV genome

$-\mathrm{C}-=$ synthetic oligodeoxyribonucleotides recognised by part of the $\mathrm{C}$ region of the HBV genome

32-P = complete, radiolabelled HBV DNA probe

* Per cent of samples positive for at least one oligodeoxyribonucleotide probe

†Per cent of samples positive for the complete, 32P-labelled HBV DNA probe

PRESENCE OF HBV DNA IN ACUTE HEPATITIS B

Serum samples from 25 patients with acute hepatitis B were collected on their first day of admission to the infectious diseases department of the University of Ancona. Ten (eight $\mathrm{HBeAg}$ positive and two antiHBe-positive) out of $25(40 \%)$ samples from these patients showed positive hybridisation signals, while $15(60 \%)$ were negative when hybridised using both the complete and the synthetic oligonucleotide probes (table 1).

HBV DNA DETECTION IN SERA OF HBA A CHRONIC CARRIERS TREATED WITH INTERFERON

HBV DNA was tested in six HBsAg chronic carriers with different degrees of evolving chronic hepatic damage and treated with recombinant $\alpha$-interferon (3 million units/daily for three days/week for three months) (table 2). In a follow up survey during treatment progressive decrease in terms of positive signals was observed in five out of six patients; in particular, in three cases the $C$ probe was no longer able to detect HBV DNA after 60 days: on the other hand, the $S$ probe still gave positive results. In these cases this pattern was predictive of $\mathrm{HBeAg} /$ anti-HBe seroconversion (data not shown) and complete clearance of detectable HBV DNA.

\section{Discussion}

The detection of HBV replication is of major importance in clinical laboratories. In fact, serum $\mathrm{HBeAg}$ positivity has been shown to be associated with HBVreplication, serum infectivity, and presence of serum HBV DNA in almost all chronic carriers tested. ${ }^{1314}$ Conversely, HBV DNA positivity in anti-HBe positive/HBsAg carriers may indicate that persistent replication is developing in spite of $\mathrm{HBe} /$ anti-HBe seroconversion, and that the patients risk severe, chronic liver disease. ${ }^{1516}$

In this study we investigated the use of non-radioactive oligodeoxyribonucleotides for detecting HBV DNA in the sera of patients with acute or persistent $\mathrm{HBV}$ infection. In our opinion, several general aspects may particularly lead to the use of synthetic oligonucleotides as probes; firstly, recent reports clearly discuss the possibility of spurious hybridisation when

Table 2 Serum $H B V D N A$ detected by $S$ and $C$ probes of $H B V$ genome in $H B s A g$ chronic carriers treated with interferon

\begin{tabular}{|c|c|c|c|c|c|c|c|c|}
\hline \multirow[b]{3}{*}{ Case No } & \multicolumn{8}{|c|}{ Serum $H B V D N A$ during treatment (days) } \\
\hline & \multicolumn{2}{|l|}{0} & \multicolumn{2}{|l|}{30} & \multicolumn{2}{|l|}{60} & \multicolumn{2}{|l|}{90} \\
\hline & $-S$ & $-C$ & $-S$ & $-C$ & $-S$ & $-C$ & $-S$ & $-C$ \\
\hline 01 & + & + & - & - & - & - & - & - \\
\hline 02 & + & + & - & - & - & - & - & - \\
\hline 03 & + & + & + & + & + & - & - & - \\
\hline 04 & + & + & + & + & + & + & + & + \\
\hline 05 & + & + & + & + & + & - & - & - \\
\hline 06 & + & + & + & - & + & - & - & - \\
\hline
\end{tabular}

-S- = synthetic oligodeoxyribonucleotides recognised by part of the S region of the HBV genome

$-\mathrm{C}-=$ synthetic oligodeoxyribonucleotides recognised by part of the $\mathrm{C}$ region of the $\mathrm{HBV}$ genome 
HBV DNA probes contain or are contaminated with plasmid sequences. ${ }^{17-19}$ In this case hybridisation with some episomal DNA present in human tissue may occur, thus giving false positive results. This possibility has mainly been related to DNA extracted from human tissues, but it may also involve serum DNA. Accurate purification of inserted HBV DNA is needed when cloned genomes are used as probes, whereas in our assay the specificity of the synthetic probes was satisfactorily guaranteed. The specificity of the oligodeoxyribonucleotide probes was assayed with several samples of viral and non-viral DNA (cytomegalovirus, Epstein Barr virus, plasmid pBR322, herring and salmon sperm, human placental, Escherichia coli DNA). Secondly, a routine method calls for the wide distribution of stable materials: both enzyme labelled and unlabelled synthetic oligonucleotides are stable for months at low temperature. Recently, a 21 nucleotide sequence probe, end-labelled with ${ }^{32} \mathrm{P}$, was tested for HBV DNA detection in serum by spot hybridisation. ${ }^{20}$ Use of oligonucleotides, it was emphasised, makes the assay simpler and faster, but even in that case all the problems due to the use of radioactive material clearly remained.

A third aspect concerns the sensitivity of the test. Generally, molecular hybridisation methods have exhibited high levels of sensitivity in detecting specific DNA sequences when ${ }^{32} \mathrm{P}$-labelled probes are used. Sensitivity of non-radioactive methods is generally lower and problems of interpreting results may be present when borderline samples are tested. Additionally, spotting serum samples on to nylon or nitrocellulose filters directly may make a radioactive method easier, ${ }^{4}$ but it may also interfere with the reading of low levels of enzymatic reaction. These are the main reasons why we adopted the DNA extraction procedure reported above, which allows results to be read more easily.

A method of amplifying short DNA fragments that enhances the sensitivity of hybridisation procedures has recently been described, ${ }^{21}$ and preliminary results on HBV DNA detection using a short (128 nucleotides), ${ }^{32} \mathrm{P}$-labelled DNA fragment complementary to part of the S gene have been satisfactory. ${ }^{22}$ Clearly, the application of this assay to HBV DNA detection using a non-radioactive method could be of great interest.

Our results indicate that, although a low concentration of HBV DNA has been detected using the complete ${ }^{32} \mathrm{P}$-labelled probe in three samples giving negative results when using the oligonucleotide probes, the sensitivity of the two cold probes used was acceptable for diagnostic purposes. The results obtained in terms of prevalence of HBV DNA positive/HBsAg carriers by using the synthetic probes are in line with previous data obtained using a complete ${ }^{32} \mathrm{P}$-labelled probe. ${ }^{16}$
Furthermore, because one of the main purposes of HBV DNA detection in human sera is to have a handy tool to test sequential samples from treated chronic carriers, we examined the sera of patients treated with $\alpha$-interferon. The loss of positivity using the oligonucleotide probe for the $\mathrm{C}$ region of the $\mathrm{HBV}$ genome was faster during treatment than for the $\mathrm{S}$ probe. This probably reflects the lower detection rate observed with the second oligonucleotide, and the different sensitivities of the two probes probably reflect the higher sequence variation in the region homologous to the $\mathrm{C}$ probe, compared with the region homologous to the $\mathrm{S}$ probe, among different subtypes. It was also predictive of the decrease in HBV DNA and, in three cases, of $\mathrm{HBe} /$ anti-HBe seroconversion, and of the complete clearance of $\mathrm{HBV}$ replication.

In conclusion, the results point to the usefulness of synthetic oligodeoxyribonucleotides as cold probes for the detection of HBV DNA in sera by spot hybridisation, thus highlighting this technology as an important tool in the survey of $\mathrm{HBV}$ infection in clinical laboratories. In our opinion, this alternative approach using non-radioactive probes is clearly of value, and further development and improvement may well generate diagnostic assays for general use. One possible approach would be to use several oligonucleotides from regions of the genome which show little sequence variation between viral subtypes, because if appropriately chosen, there would be no steric hindrance and a stronger signal.

We thank Giorgio Scalise for providing sera from patients with acute hepatitis B and John F Sidaway for reviewing the manuscript. This work was supported by grants from "Consiglio Nazionale delle Ricerche" (CNR) Progetto Finalizzato "Biotecnologie e Biostrumentazione".

\section{References}

1 Tiollais P, Pourcel C, Dejan A. The hepatitis B virus. Nature 1985;317:489-95.

2 Liaw YF, Pao CC, Chu CM. Changes of serum HBV DNA in relation to serum transaminase level during acute exacerbation in patients with chronic type B hepatitis. Liver 1988;8:231-5.

3 Shafritz DA, Shouval D, Sherman HI, Hadziyannis SJ, Kew MC Integration of hepatitis B DNA into the genome of liver cells in chronic liver disease and hepatocellular carcinoma. $N$ Engl $J$ Med 1981;305:1067-73.

4 Scotto J, Hadchouel M, Hery C, Yvart J, Tiollais P, Brechot C. Detection of hepatitis B virus DNA in serum by a simple spot hybridization technique: comparison with results from other viral markers. Hepatology 1983;3:279-84.

5 Kam W, Rall L, Smuckler E, Schmid R, Rutter W. Hepatitis B viral DNA in liver and serum of asymptomatic carriers. Proc Natl Acad Sci USA 1982;79:7522-6.

6 Krogsgaard K, Aldershville J, Kryger P, Andersson P, Nielsen JO, Hansson BG and The Copenhagen Hepatitis Acuta Programme. Hepatitis B virus DNA, HBeAg and delta infection during the course from acute to chronic hepatitis B virus 
infection. Hepatology 1985;5:778-82.

7 Brigati DJ, Myerson D, Leary JJ, et al. Detection of viral genomes in cultured cells and paraffin-embedded tissue sections using biotin-labelled hybridization probes. Virology 1983;126:32-50.

8 Donovan RM, Bush CE, Peterson WR, et al. Comparison of non radioactive DNA hybridization probes to detect human immunodeficiency virus nucleic acids. Mol Cell Probes 1987;1:359-66.

9 Larzul D, Thiers V, Courouce AM, Brechot C, Guesdon JL. Nonradioactive hepatitis B virus DNA probe for detection of $\mathrm{HBV}$ DNA in serum. J Hepatol 1987;5:199-204.

10 Galibert F, Mandart E, Fitoussi F, Tiollais P, Charnay P. Nucleotide sequence of the hepatitis B virus genome (subtype ayw) cloned in E coli. Nature 1979;281:646-50.

11 Ono Y, Onda H, Sasada R, Igarashi K, Sugino Y, Nishioka K. Complete nucleotide sequences of cloned hepatitis B virus DNA; subtype adr and adw. Nucleic Acid Res 1983;11:1747-59.

12 Rigby PWJ, Dieckmann M, Rhodes C, Berg P. Labeling deoxyribonucleic acid to high specific activity in vitro by nick translation with DNA-polymerase I. J Mol Biol 1987;113: 237-51.

13 Weller JVD, Fowler MJF, Monjardino J, Thomas HC. The detection of HBV DNA in serum by molecular hybridization: A more sensitive method for the detection of complete HBV particles. J Med Virol 1982;9:273-80.

14 Carloni G, Delfini C, Colloca S, Alfani E, Taliani G, De Bac C. Incidence of hepatitis B virus DNA and DNA-polymerase in sera of Italian asymptomatic carriers with the serological markers of HBV. Arch Virol 1986;87:97-105.
15 Bonino F. The importance of hepatitis B viral DNA in serum and liver. J Hepatol 1983;3:136-41.

16 Carloni G, Colloca S, Delini C, Manzin A, Clementi M, Galibert F. Detection of HBV infectivity by spot hybridization in HBeAg-negative chronic carriers: HBV DNA in sera from asymptomatic and symptomatic subjects. J Med Virol 1987; 21:15-23.

17 Hino O, Kitagawa T, Sugano H. Bacterial contamination of human tumor samples. Science. 1984;225:670-1.

$18 \mathrm{Gu}$ JR, Chen YC, Jiang HQ, et al. State of hepatitis B virus DNA in leukocytes of hepatitis B patients. J Med Virol 1985;17:73-81.

$19 \mathrm{Gu} \mathrm{JR}$. Molecular aspects of human hepatic carcinogenesis Carcinogenesis 1988;5:697-703.

20 Lin HJ, Wu PC, Lai CL. An oligonucleotide probe for the detection of hepatitis B virus DNA in serum. $J$ Virol Methods 1987;15:139-49.

21 Saiki RK, Scharf S, Faloona F, et al. Enzymatic amplification of B-globin genomic sequences and restriction site analysis for diagnosis of sickle cell anemia. Science 1985;230:1350-4.

22 Larzul D, Guigue F, Snisky JJ, Mack DH, Brechot C, Guesdon JL. Detection of hepatitis B virus sequences in serum by using in vitro enzymatic amplification. J Virol Methods 1988;20:227-37.

Requests for reprints to: Dr Aldo Manzin, Institute of Microbiology, Service of Virology, Regional Hospital of Torrette, I-60020 Ancona, Italy. 